\title{
Count the Limbs: Designing Robust Aggregation Clauses in Sovereign Bonds
}

Anna Gelpern

Georgetown University Law Center, ag1348@law.georgetown.edu

Ben Heller

Hutchin Hill Capital, ben.heller@hutchinhill.com

Brad Setser

Roubini Global Economics, LLC; University College London, brad.setser@rgemonitor.com

This paper can be downloaded free of charge from:

https://scholarship.law.georgetown.edu/facpub/1793

http://ssrn.com/abstract=2817666

Too Little, Too Late: The Quest to Resolve Sovereign Debt Crises (Initiative for Policy Dialogue at Columbia 2016)

This open-access article is brought to you by the Georgetown Law Library. Posted with permission of the author. Follow this and additional works at: https://scholarship.law.georgetown.edu/facpub

Part of the Banking and Finance Law Commons, Contracts Commons, and the International Trade Law Commons 


\title{
Count the Limbs: Designing Robust Aggregation Clauses in Sovereign Bonds
}

\author{
Anna Gelpern, Ben Heller and Brad Setser ${ }^{1}$
}

On August 29, 2014, the International Capital Market Association (ICMA) published new recommended terms for sovereign bond contracts governed by English law (ICMA 2014b). The change would allow a super majority of creditors to approve a debtor's restructuring proposal in one vote across multiple bond series. The vote could bind all bond holders even if one series voted unanimously against restructuring, so long as enough holders in the other series voted for it. This apparently technical change, awkwardly named "single-limb aggregated collective action clauses" promised to eliminate free-riding holdouts for the first time in the history of sovereign bond restructuring. A single vote across different bond issues could also open up new possibilities for abuse.

The markets might have rebelled. Instead, they yawned. On October 7, barely a month after ICMA launched its new collective action clauses (CACs), Kazakhstan became the first to use them in an English law bond. The issue, Kazakhstan's first in fourteen years, was oversubscribed by a factor of four. ${ }^{2}$ Vietnam adapted the mechanism in an unregistered $\$ 1$ billion New York-law bond within a month with no apparent pushback from investors, despite being well below investment grade (at BB-). In November, investment-grade Mexico inserted a streamlined version of single-limb aggregation in its multi-billion dollar New York-law bond program. Mexico's size and prominence among emerging market issuers ensured that its choice of contract terms would be closely watched in the market. During a conference call hosted by Mexico's investment bankers to introduce the new CACs, not one investor objected or asked a question (JPMorgan 2014). The November issue set the record for the lowest yield and lowest coupon of any 10-year U.S. dollar bond issued by the Mexican government (Diaz de Leon 2016). Half a dozen other countries adopted single-limb aggregation within months; each launch was equally uneventful. The financial press greeted the news with a smattering of articles and editorials, calm in tone and broadly supportive in substance.

Flash back twelve years. The pages of the Financial Times and the Wall Street Journal sizzled with opinion columns from prominent academics debating proposals to neutralize holdouts. A high-profile contest between contract reforms to empower a super-majority of creditors and a treaty-based sovereign debt restructuring mechanism (SDRM) fueled a stream of news stories in

\footnotetext{
${ }^{1}$ Anna Gelpern is a professor of law at Georgetown University. Ben Heller is a fund manager at Hutchin Hill. Brad Setser is Deputy Assistant Secretary for International Economic Analysis at the U.S. Treasury. The opinions in this essay are ours alone. The views expressed in the article do not reflect nor are they intended to represent the views of the Department of the Treasury or the government of United States. The authors would like to thank Mark Sobel, Him Das, Francine Barber and Domenico Lombardi for comments. An edited version of this paper will appear in Too Little, Too Late: The Quest to Resolve Sovereign Debt Crises (Initiative for Policy Dialogue at Columbia: Challenges in Development and Globalization) (M. Guzman, J.A. Ocampo and J.E. Stiglitz, eds., forthcoming 2016).

${ }^{2}$ Kazakhstan was not shy. It placed a thirty year bond at a yield of around 5 percent. Bids totaled $\$ 11$ billion for $\$ 2.5$ billion (face) of bonds on offer.
} 
2002 and 2003. Back-to-back speeches by Stanford economists Anne Krueger and John Taylor, then number two at the IMF and the U.S. Treasury, respectively, gave the battle epic academic and policy stature, and an air of Beltway intrigue (Krueger 2002, Taylor 2002). Investor groups sprang up to resist all official sovereign debt restructuring initiatives as creeping encroachments on creditor rights. Analysts predicted that bond markets would shun sovereigns for deviating from the prevailing contract boilerplate. Emerging market finance ministers agonized over these predictions, and fumed at IMF and Group of Seven officials for sticking their noses into other people's contracts and sowing doubts in the markets about sovereigns' ability and willingness to pay (Setser 2010). Few if anyone believed the more extravagant claims made by reform advocates — that majority amendment terms in sovereign bonds would make it possible to scale back IMF lending (Gelpern and Gulati 2006).

Mexico launched the first SEC-registered bond with majority-amendment CACs in February 2003, departing from the New York custom of giving each bondholder a veto over contract amendments. By all accounts, it did so primarily to recapture its own debt narrative and block SDRM; fighting holdouts was a secondary objective at best (Gelpern and Gulati 2013). Perhaps as a result, the change looks modest in retrospect: each series of bonds must vote separately, so that any series where objectors held a blocking minority could drop out of the restructuring. Nevertheless, investors on the conference call with Mexico’s underwriters were outraged and threatened to boycott the issue.

It turns out that the amplitude of public debate and market resistance are poor proxies for the magnitude of change. The new generation of aggregated CACs goes some way toward bridging the gap between corporate and sovereign bankruptcy. Once widely adopted, single-limb aggregation would introduce-by contract - a basic bankruptcy concept of voting by class, rather than by instrument, in sovereign bonds governed by foreign law (IMF 2003b). As a result, single-limb aggregated CACs are likely to have a much bigger impact on sovereign restructurings than the series-by-series CACs introduced in New York in 2003 and long customary in the London market.

The relatively smooth introduction of potent contract changes in 2014 has many explanations. Substance and process learning are surely a big part of the story. Substance learning came from over a decade of experience with series-by-series CACs, which helped on the margins in several small restructurings, but were hardly revolutionary (Das, Papaioannou and Trebesch 2012, Duggar 2013). “Two-limb” aggregation clauses with both stock-wide and series-by-series polling had been introduced in Uruguay (2003), Argentina (2005), and most importantly, across euro area sovereign bonds (2013)_although they had not been used in a restructuring (Gelpern and Gulati 2013). CACs had become mainstream: constructive and inoffensive. On the other hand, the Greek debt restructuring in 2012 and never-ending litigation stemming from Argentina's 2001 default revealed vulnerabilities in series-by-series CACs. In Greece, blocking positions led more than half of all foreign law bonds to drop out of the restructuring, even though most Greek foreign law bonds had CACs. These bonds continue to be paid in full (Zettelmeyer, 
Trebesch and Gulati 2013). In the case of Argentina, rulings by U.S. federal courts in favor of holdouts beginning in 2011 effectively blocked payments on restructured bonds unless the government paid the holdout plaintiffs in full, potentially upsetting the delicate balance between risk and reward that drove investor participation in earlier restructurings. As we write, neither the holdouts nor the restructured bond holders in Argentina are getting paid. Judicial rulings inadvertently demonstrated the perils of incomplete restructuring that had preoccupied theoretical literature in the 1990s (Eichengreen and Portes 1995, Brooks et al. 2015).

Process learning was at least as important. On the one hand, finance officials on all sides emerged bruised from the battles of 2003 and sought to avoid reviving the standoff between statute and contract, despite pressure from some borrowing governments, academics and civil society groups. ${ }^{3}$ In a sign of the times, the IMF endorsed the new clauses less than a month after they were proposed (IMF 2014a).A parallel process at the U.N. General Assembly stopped short of a binding treaty and chose for now to articulate broad-based restructuring norms (UN 2015). On the other hand, the adoption of CACs beginning in 2003 had created a process playbook, where all stakeholders could coalesce around model contract language without being bound. The words would not be mandatory, and could be adapted to individual country circumstances, but would enjoy a form of "compliance pull” from endorsements by diverse governments, multilateral organizations, and market associations.

ICMA's 2014 model clauses emerged out of a working group convened by Mark Sobel of the U.S. Treasury staff in 2013 to coordinate approaches to contract reform. The group included debt managers from mature and emerging market countries, IMF officials, lawyers, investors and investment bankers. ${ }^{4}$ The robust discussion inside the working group helped build consensus on the nature of the needed reform and the trade-offs intrinsic in any new voting mechanism. In addition, informal consultations with market participants and other stakeholders took the better part of two years and contributed to the development of the new generation of CACs (eg, ICMA 2014a).

In sum, the prevailing approach to sovereign debt restructuring reform requires agreement on contract design. As a matter of design, moving from unanimity to super-majority approval in New York in 2003 was relatively simple, especially since majority voting had already been the practice in London. Design was a bigger challenge in moving from series-by-series to robust cross-series voting in 2014. The new terms had to preserve the balance of power between debtors and creditors, empower a majority of creditors, neutralize free-riders, and protect minorities from abuse. This balancing had to be achieved with no statutory guidance or court oversight, which in

\footnotetext{
3 The financial crisis and regulatory reform experience since 2008 may have put the stakes in perspective for all involved.

${ }^{4}$ The authors all participated in the informal working group on contract reform hosted by the U.S. Treasury Department.
} 
bankruptcy help ensure that creditors voting as a class share the same interests. As with most matters in sovereign debt, it was all down to contract.

Contract design is our focus for the remainder of this essay. We start by briefly reviewing the introduction of series-by-series voting to amend financial terms into New York-law bonds in 2003. We then look at the factors that helped create broad consensus on the need to move beyond series-by-series voting in 2012. Most of the essay is devoted to analyzing the key features of the new generation of aggregated CACs and the considerations that shaped decisions about these features. We conclude with observations on contract reform in sovereign debt restructuring and the challenges ahead.

\section{CACs in New York Law Bonds: 1996-2003}

In 2015, it is hard to make sense of the 1996 to 2003 controversy over arcane boilerplate in New York -law sovereign bond contracts. The terms at the heart of intense public debates were simple and not entirely novel. English law bonds had long permitted creditor majorities to amend financial terms in sovereign bonds (Weidemaier and Gulati 2011). New York-law bonds did the same for non-financial terms, but required unanimous bondholder consent to change maturity, interest rate, currency, and the like. Mechanically, reforms first proposed in 1996 and ultimately implemented in 2003 could be accomplished by changing a few words in New York boilerplate (Group of 10 1996, Buchheit 1998, Group of 22 1998). English-law contracts did not need to change at all. ${ }^{5}$

The symbolism of shifting from veto power for every bondholder to qualified majority rule offers part of the explanation. For some market participants, unanimity stood for bonds' special immunity from restructuring, with roots in the Brady bonds of the late 1980s and early 1990s. The Brady bonds delivered substantial debt relief in exchange for a special commitment to pay, which ended the cycle of syndicated loan renegotiations and paved the way for emerging market sovereigns to access the global capital markets (Cline 1995).

New York-law Brady bonds could only be amended with unanimous consent of all bondholders. As a technical matter, this did not immunize them from restructuring. Instead of amending its bond contracts, a sovereign could offer to exchange them for new ones. With the right incentives, most of the bondholders were likely to choose new, performing bonds over the prospect of default and years spent fighting to overcome sovereign immunity and scouring the world for attachable government assets. Within a decade of the first Brady bond deal, techniques such as exit consents and minimum participation thresholds paved the way for a string of relatively

\footnotetext{
${ }^{5}$ English-law contracts evolved in reaction to innovations in New York, mostly with respect to voting mechanics and safeguards against manipulation (Gelpern and Gulati 2009)
} 
speedy debt exchanges, which delivered substantial debt relief (Panizza et al. 2009, Bi et al. 2009). ${ }^{6}$

As bond exchanges gathered momentum, more and more market participants argued that the official sector's war on unanimity in New York was misguided. Bond restructuring took less time than haggling with banks in creditor committees and dealing with their regulatory accounting constraints. CACs were a solution in search of a problem.

Yet to some in the official sector, CACs were the key to ending the era of big bailouts that started with Mexico in 1994 (Taylor 2007). Here too, symbolic arguments made more sense than functional ones. The idea that New York-law contract changes could reduce the need for IMF lending ignored the fact that Mexico’s vulnerability stemmed not from its foreign law bonds, but from dollar-indexed domestic law tesobonos, which might have been restructured unilaterally. The next round of bailouts responded to the crisis in Asia, with roots in cross-border interbank and corporate borrowing, not sovereign bonds. Russia, Brazil and Turkey secured large IMF packages when the cost of rolling over their local currency, local law Treasury bills became prohibitive (Roubini and Setser, 2004). Only in Argentina in 2001 did foreign bonds lie at the heart of the crisis and, even there, resolving the crisis would take much more than an orderly bond restructuring. For example, Argentina lost more reserves from deposit flight than bond repayment in 2000 and 2001 (Rosenberg et al. 2005, Setser and Gelpern 2006).

Classic arguments over sovereignty loomed large over the debate about bailouts and bail-ins. For most U.S. officials, the idea that a treaty could trump financial contracts under New York law, or that an international body could trump U.S. courts was simply unacceptable (Quarles 2010). On the other hand, many market participants had an almost totemic attachment to the idea that "foreign law" and contracts properly drafted under the laws of a major financial jurisdiction would protect them from opportunistic sovereign debtors, even though only a handful of them had ever tried to vindicate their rights in court (Porzecanski 2010).

Symbolism aside, the essential design change needed to bring the debate to an end was simple. The line in the contract that said that each bondholder had to consent to amend the bond's financial terms had to be struck. A new line specifying the super-majority needed to amend the terms would take its place.

Of course more could be done, and was done. Dislodging “sticky” boilerplate opened up the space to reconsider other terms in the contract, both those closely connected to the new majority

\footnotetext{
${ }^{6}$ With exit consents, debtors asked bondholders participating in a debt exchange to vote in favor of amending nonfinancial but nevertheless important terms in the old bonds on their way out of them. If a majority voted to amend, nonparticipating bonds became illiquid and, in some cases, unenforceable (Buchheit and Gulati 2003). While done within the "four corners" of the contract - and arguably central to the success of exchanges - exit consents worried creditors, who saw considerable potential for abuse. The restructuring process was riding too hard on using amendment provisions for a purpose other than they had been intended. To some, this suggested that creditors should take initiative in creating a fairer process for amending financial terms, but this wasn't the consensus view of creditors at the time.
} 
amendment terms, and others only tangential relevant to them. An important but rarely mentioned set of changes in English law sovereign bonds brought them closer to the standard emerging in New York. For example, the effective threshold required to bind all bondholders went up, as more contracts counted votes as a percentage of aggregate principal outstanding, in place of the London market custom of counting bonds represented in a quorate meeting. In New York and London, the list of terms requiring supermajority consent for amendment grew longer to limit the scope for exit consents, which came to look coercive in the eyes of market participants after a string of bond exchanges. On the other hand, many issuers added terms that made it harder for individual creditors to accelerate and enforce their bonds (Bradley and Gulati 2012, Weidemaier and Gulati 2014). Concerns about conflicts of interest, such as sovereign debtors and entities controlled by them voting the bonds, ${ }^{7}$ led to the introduction of disenfranchisement clauses, which deemed bonds owned or controlled by the debtor not to be “outstanding” for voting purposes.

Other terms were mooted but did not spread. For example, a drafting group made up of law practitioners who prepared model clauses under the auspices of the Group of Ten shortly before Mexico switched to CACs in 2003, recommended that issuers consider using trustees to represent bondholders as a group and block lawsuits by individual holdouts (G10 2002). Other suggestions included appointment of a negotiating representative in crisis, information disclosure and moving toward a form of aggregated voting across multiple series.

ICMA issued recommendations for CACs in 2004 that were broadly in line with the G-10 recommendations (ICMA 2004). ICMA's model also advised sovereigns to pre-commit in their contracts to engage with creditor committees in the event of a restructuring. Some emerging and mature market issuers in the London market adopted such "engagement” clauses; almost none did in New York.

In sum, starting in 2003, virtually all new foreign-law bonds issued by emerging market sovereigns in New York and London contained some form of supermajority amendment terms to facilitate the bond restructuring process. Changes in other parts of the contract responded to restructuring experience and concerns about new risks from CACs. Sovereigns experimented on the margins with designing CACs and safeguards. Nevertheless, long maturities and residual skepticism among a few issuers (notably China) meant that transition from unanimity to supermajority voting would take time. As of 2014, the IMF estimated that approximately a quarter of all outstanding New York-law emerging market bonds, and approximately one-fifth of all foreign law emerging market bonds still required unanimous bondholder approval to amend financial terms (IMF 2014a).

\footnotetext{
${ }^{7}$ CIBC Band \& Trust Co. v. Banco Cent. do Brasil (886 F.Supp. 1105 (1995)
} 


\section{Evolution to Revolution: 2003-2013}

Despite a splash of publicity at the outset, the shift that began in 2003 had no material impact on the new issuance market. Foreign law bonds with CACs traded like bonds without them. ${ }^{8}$ Variations on CACs no longer made the news; they returned to law firm conference rooms from whence they came.

Sovereign bond restructurings since 1997 suggested that CACs could be helpful, especially in small countries with a concentrated creditor base. Ukraine used CACs indirectly to amend three bonds and raise participation in its 2000 debt exchange. Uruguay used CACs to restructure a small Japanese law bond, but otherwise relied on the familiar combination of exchange offer and relatively mild exit consents in its 2003 debt operation (Buchheit and Pam 2004). Moldova, Belize, Seychelles, St. Kitts and Nevis, and Cote d'Ivoire all used CACs to amend their bonds (Duggar 2013). But a couple of countries that had CACs in their English law bonds, notably Pakistan back in 1999, chose not to use them at all. They were useful, but hardly indispensable.

Aggregated CACs first introduced by Uruguay in 2003 might have been a different matter. Uruguay's new bonds were issued as part of a comprehensive restructuring, replacing virtually the entire stock of its foreign debt. They allowed a full restructuring of all bonds with a vote of three quarters of all the bonds taken together and two thirds of each bond series. The lower perseries threshold would require holdouts to control more than one-third of a series to ensure that their bonds dropped out of a restructuring, compared to one-quarter in series-by-series CACs. Uruguay had initially mooted aggregation with a stock-wide vote only, but revived series-byseries voting as a parallel requirement when creditors complained. The new mechanism came to be known as "two-limb aggregation.” It was the most significant precursor of the 2014 CACs; however, for a long time, it remained a minor footnote in emerging market debt, introduced in a comprehensive restructuring and never tested either in the primary issuance market, or as a tool in an actual restructuring.

\footnotetext{
${ }^{8}$ Scores of academic pricing studies were so inconsistent, they looked incoherent. Some argued that CACs came with a price penalty. Others that they carried a benefit-for the same countries. Yet others suggested no impact at all, though their explanations varied. All the studies pointing in different directions agreed on one thing: to the extent CACs had an impact on bond prices, it was very small See Becker, Thaicharoen,and Richards 2003; Eichengreen and Mody, 2004; and Bradley and Gulati 2012. A simple plot of yield curve never suggested that CACs carried a price penalty. For example, bonds with the new aggregation clauses trade in line with bonds that lack the new aggregation clauses of the same maturity. However, there is evidence that some legal provisions start to have an impact on market pricing as bonds slide closer to default.
} 
Meanwhile, the risk of litigation in sovereign bond restructuring was no longer hypothetical. While still low, the incidence of lawsuits has increased dramatically since the 1980s (Schumacher et al. 2012, IMF 2013). To be sure, there is nothing wrong with lawsuits per secontracts are supposed to be enforceable in court (Fisch and Gentile 2005). The trouble with suing sovereign governments is that courts have limited power to fashion effective remedies against them, since most of their assets are inside their borders or immune from seizure. For a long time, this meant that lawsuits could irritate and embarrass governments into settling with holdouts, but could do little to disrupt restructurings or harm bystanders.

Argentina’s \$86 billion default in 2001, followed by two rounds of restructuring in 2005 and 2010, changed all that.

The foreign bonds at the heart of Argentina's crisis were issued under New York law in the 1990s; they had no CACs. Even so, the government's first exchange offer in 2005 attracted just over three-quarters of its bondholders, a lower participation rate than any other bond exchange that could not or chose not to use CACs. Commentators and market participants blamed the low take-up on Argentina's confrontational negotiating style and stingier-than-expected financial terms, not on any deficiency in the restructuring architecture (Porzecanski 2005). A second exchange in 2010 brought participation to 93 per cent. All the while, the government had been fighting thousands of lawsuits, mostly in Argentina. For the first decade after Argentina's crisis, creditors who sued under foreign law in Europe, Asia, and the United States had little to show for their efforts. However, in 2011, one group of holdout creditors appeared to hit paydirt: a U.S. federal court in New York enjoined payments on Argentina's restructured bonds issued in 2005 and 2010 until the holdouts were paid in full.

The remedy was based on another standard term in the bond contract, the pari passu clause, which had promised to treat creditors "in equal step” with one another and had served as rich fodder for arcane academic debates about the meaning of equality outside bankruptcy. The injunction upended the balance at the foundation of sovereign debt restructuring. Litigation turned from an irritant into a full-blown boycott, threatening bondholders, payment intermediaries, clearing houses, and pretty much anyone else who could serve as a link between Argentina and the global financial markets (Weidemaier and Gelpern 2013). At this writing, Argentina still refuses to pay the holdouts — and has been unable to pay its restructured bonds or raise new debt since 2014. While the benefit of holdout strategy remains unrealized, the damage has metastasized. Those who argue that the injunctions are unimportant say that Argentina is "unique," in the sense that its restructuring tactics uniquely justify the nuclear remedy of enjoining a country from making any payments on its new, restructured bonds unless it paid its old, unrestructured bonds in full, including all past due interest. Such reasoning is small comfort to other emerging market issuers, who have started disclosing U.S. federal court rulings as a risk factor in new offering documents. 
Between 2003 and 2013, investors in the emerging markets also shifted focus to bonds denominated in local currency and governed by local law. After a string of crises with roots in currency mismatches between the assets and liabilities of emerging market economies, governments changed their approaches to saving and borrowing. They began accumulating large stocks of foreign currency reserves, reduced their need to issue foreign currency debt, and sought to borrow more at home. Borrowing in local currency would reduce mismatches and deepen local financial markets (Eichengreen and Hausmann 1999; IADB 2006). At the same time, investors sought local market exposure to profit from the expected appreciation of many emerging market currencies. Some governments initially offered local currency debt governed by foreign law; however, investors were apparently unwilling to pay much for this feature, and it disappeared quickly (Tovar 2005). Investors proved quite happy to accept local law for their local currency exposure. This was mildly puzzling, since investors who entered the local markets could hardly expect robust legal protections in crisis. Russia restructured local law debt in 1998; Argentina did it in 2002. Neither showed much concern for investor protections. Despite or because of this experience with domestic restructurings, no one broached the idea of introducing CACs in domestic law emerging market bonds.

When the Greek debt crisis began spreading across the euro area in 2010, sovereign debt restructuring architecture went from being a cyclical preoccupation in a $\$ 600$ billion market for emerging market debt to being the focus of attention in a 10 trillion euro market, overnight. One of the earliest responses to the debt crisis by European policy makers was to announce in the fall of 2010 that all new euro area sovereign bonds should use CACs. The obligation to use clauses took effect in 2013, and the euro area's drafting committee choose to make two-limb aggregated CACs the standard in all euro area government bonds, foreign and domestic (Gelpern and Gulati 2013). Compared to market practice in both New York and London, euro area CACs had lower voting thresholds for each of the two "limbs," notably 2/3 of the principal outstanding for all of the affected series, combined with 50 per cent of the principal outstanding for each of the affected series, when voting by written resolution. (EFC Sub-Committee on EU Sovereign Debt Markets 2012). Euro area CACs also had more flexible disenfranchisement provisions, which would allow state-owned entities with "autonomy of decision” (including central banks and public pension funds) to vote government bonds.

Despite the energy poured into euro area contract changes, the Greek debt restructuring of 2012 was carried out with little help from contracts. Like other euro area issuers, Greece had issued most of its debt under its own law. When time came to restructure, it enacted a law that allowed all of its local bonds to vote together in a single up-or-down vote, and bind the dissenters. This statutory mechanism was cleverly marketed as a collective action clause, broadly reflecting the view that bondholder democracy was the basis of any legitimate sovereign restructuring. In all other respects, Greek “retro-CACs” had little in common with any other CACs: they were inserted in Greek contracts unilaterally by statute after the start of the crisis, not negotiated at the time of borrowing. They also included quorum and voting thresholds calculated to secure 
acceptance of the government's offer. The Greek model was functionally closer to class-wide voting in corporate bankruptcy than the prevailing bond-by-bond CACs.

The Greek restructuring also served as a graphic demonstration of the limits of series-by-series CACs. While foreign bonds were less than ten per cent of the government's debt stock, they became a magnet for holdouts. Restructuring votes failed in nine out of seventeen foreign law issues that Greece attempted to restructure. Slightly half of the total outstanding principal under foreign law Greek bonds stayed outside the restructuring and, importantly, continued to be serviced on schedule. Most of the holdout bonds were governed by English law (Zettelmeyer, Trebesch and Gulati 2013).

The success of statutory retro-CACs and failure of traditional series-by-series CACs in Greece together paved the way for CACs to come.

\section{New Model Needed: 2013-2014}

When the U.S. Treasury staff convened a group of issuers, investors, academics and legal practitioners in the fall of 2013, the atmospherics were completely different from 2002. There were no G-7 or G-20 calls for a brand new restructuring architecture. There was no talk of contract reform ending the era of big bailouts. Instead, the focus was on realistic and achievable changes to address two clearly defined problems: injunctions against Argentina and the failure of bond by bond CACs to secure broad participation in Greece's restructuring. In another contrast to 2002, the IMF joined the Treasury in promoting contract change. The IMF staff took SDRM off the table at the start, declaring that there was no support for revisiting treaties in its governing board. All energy went into contract design.

The wave of reforms at the turn of the century and the gradual adaptation and learning that went on since then were essential prerequisites to the 2014 changes. Nevertheless, the new low-key process led to a far bigger change in sovereign bond documentation than what had emerged from the public battles of the 1990s and early 2000s.

New clauses went beyond anything that had been in the market in either London or New York. They allowed the issuer to dispense with series-by-series voting altogether, either as a standalone restructuring tool or as part of two-limb aggregation. The attraction of polling each series had weakened in the eyes of investors over time. Greece's single vote of all bonds delivered an outcome that mapped to investor's expectations in a case where deep restructuring was obviously necessary - and it had become clearer that series-by-series voting could be gamed. Creditors who did not have blocking positions in individual series were at a disadvantage relative to creditors who did. An outcome that treated different bond issues fairly depended on how issuers decided to handle would-be holdouts with blocking positions. The presence of potential blocking positions made negotiation more difficult by creating varied and sometimes nontransparent creditor interests. As a result the protection offered by series-by-series voting began 
to look illusory. For all but dedicated holdouts, it made good sense to embed investor protections elsewhere in the contract.

But aggregated voting across multiple issues on its own is also subject to the risk of abuse On the one hand, all bonds - as unsecured creditors of the same rank -- have an equal claim relative to the par value of the bond on the debtor's resources. On the other hand, bondholders come to the restructuring table with different financial interests and contractual claims, reflecting the terms of their bonds. Ensuring equitable treatment among them while protecting minorities entails further contract changes and creates challenging design problems.

In sum, 2013-2014 was the opposite of 2002-2003. Political symbolism was muted, while the design challenge was formidable. Successful reform required two things: broad agreement on the need for change and agreement on a template for the new design.

Consensus for change came from the obvious place: litigation against Argentina changed the game (Brooks and Lombardi 2015, Stiglitz and Guzman 2014). Until then, holding out had been perceived as a risky strategy unsuitable for all but the most determined activist investors. Participation rates were high (Das, Papaioannou and Trebesch 2012, Duggar 2013), and the smattering of non-participants had been paid or bought out. The country and the creditors that went into the new instrument could move on. This did not happen in Argentina. Creditors who had agreed to accept new bonds with, in the case of the discounts bonds, an initial face value of one-third of the old for the sake of moving on suddenly found their payments blocked. The old balance between risk and reward in sovereign restructuring was no more. While every distressed government might tell itself that it was not Argentina and did not merit the same punitive treatment, no country relished the prospect of making this argument in court. On the other hand, the appellate court rulings upholding the unprecedented injunctions against Argentina were explicit: sovereigns and their creditors were free to change their contracts if they wanted to avoid Argentina's fate. ${ }^{9}$

Thus even though few governments and fewer creditors had much sympathy for Argentina, there was little doubt that the uncertainty about future payments reduced the market value of Argentina's restructured bonds. In the summer of 2014, Argentina's benchmark discount bonds traded at yields of 10 percent (a modest discount to their par value, as they had a relatively high coupon), while the bonds of Ecuador - a worse fundamental credit even back when oil was selling for over $\$ 100$ a barrel - traded at yields of around 7\%. Clearing away the legal uncertainty would lead the bonds Argentina issued in its restructuring to trade up in value immediately. It was not difficult to show harm.

The impact of the injunction and its spillover effects compounded concerns based on growing evidence of strategic behavior by bond holders looking to build blocking positions in individual

\footnotetext{
${ }^{9}$ See NML Capital, Ltd. v. Republic of Argentina, 699 F.3d 246 (2d Cir. 2012) and NML Capital, Ltd. v. Republic of Argentina, 727 F.3d 230 (2d Cir. 2013).
} 
bonds (IMF 2014b). Series-by-series voting set a transparent target for creditors who wanted to block amendment of their bond (Makoff and Kahn 2015). The Greek restructuring validated expectations that a bond that drops out of a restructuring would be paid in full, or at worst, restructured on advantageous terms. This dictated a simple investment strategy: buy a large stake at a deep discount in a bond maturing in the near term and threaten to sue unless paid in full. Investors looking to copy the success of the Greek English law holdouts were rumored to have built up sizeable positions in near-dated Cypriot bonds governed by English law. And even after setting aside Franklin Templeton's outsized position across a broad number of Ukraine’s bonds, small groups of investors were reported to hold blocking positions in certain near-dated Ukrainian bonds (Ash 2015). ${ }^{10}$. The headaches from series-by-series voting seemed to snowball, even in England, where conventional wisdom held that the courts were unlikely to agree with the U.S. federal courts' interpretation of the pari passu clause.

Strategic free-riding using series-by-series CACs might be rational from the point of view of individual bond holders seeking to maximize returns; however, it does not necessarily serve the broader interest of all creditors. The funds paid to the holders of maturing Greek bonds governed by English law could have been used to make payments to all participants in the bond restructuring at no cost, in aggregate, to Greece. Moreover, the funds used to pay maturing Greek bonds governed by English bonds were borrowed from the euro area, adding to the burden of Greece’s official debt.

On the other hand, the experience with a binding stock-wide vote in Greece was broadly positive. The statutory retro-CAC swept in all EUR 178 billion (over $\$ 230$ billion at the exchange rate of the time) of Greece's domestic law debt. This avoided any interruption of payments and avoided a technical default. CDS were triggered by the use of statute to bind creditors into a deal, not by formal default. This allowed Greek banks to continue to get financing from the European Central Bank (ECB), whose Greek debt holdings were excluded from restructuring altogether. The outcome - all holders getting the same package of new bonds - was analogous to the results of bankruptcy, and made a certain amount of sense given Greece's deep distress and high debt levels. The resulting stock of Eurobonds has a reasonable payment structure and remained outside subsequent discussions of how to alter Greece's debt stock. After the bond restructuring, the official sector's unrestructured (in all but the most technical of senses $^{11}$ ) debt was obviously the main problem.

Despite the audacious character of retro-CACs, the fact that they had been coordinated with creditors ahead of time and supported by the Institute of International Finance (IIF) made them surprisingly uncontroversial. Investors focused instead on the exclusion of ECB and national

\footnotetext{
10 The U.S. mutual fund Franklin Templeton had been a large buyer of Ukraine's debt, and as a result of its large position, likely held over a third of many other bond issues. However there is no indication that it bought the bonds with the intent of gaining leverage over the restructuring.

${ }^{11}$ Member states did agree to change the payments profile of the debt Greece owed to the European Financial Stability Fund in 2012.
} 
central bank bonds from the restructuring. While no doubt inequitable, this outcome reflected the leverage the ECB had over the negotiations as the only possible provider of liquidity support to the Greek banking system and thus the ultimate guarantor of Greece's continued participation in the euro.

In sum, Argentina and Greece had convinced market participants and issuers that series-by-series voting could create substantial uncertainty about a country's path through debt trouble, and made it harder, not easier, for investors to price bonds as a country slipped toward default. This created an opportunity to consider changes that might result in a more predictable sovereign debt restructuring process. Discussion among practitioners, issuers and investors indicated openness to go beyond fixing the interpretation of the pari passu clause. Judges revealed a dangerous misunderstanding of series-by-series voting in their repeated observations that the advent of CACs since 2003 had made holdouts a thing of the past. The realization that series-by-series CACS alone did not end holdouts supported a quick and deep consensus on the need for robust aggregation, which could support full participation in a restructuring and let the country and the market move on.

On the other hand, the experience of contract reform in 2003 reassured issuers and market participants that well-designed process improvements such as CACs would be accepted in the market and carry no price penalty (Gelpern and Gulati 2015). We focus on the design of aggregation clauses next.

\section{Design}

Voting Options. The threshold choice for designing the new CACs is between single-limb and two-limb aggregation. Two-limb aggregation had two advantages. First, there were existing models acceptable to the market, notably the euro area's two-limb aggregated CACs with low approval thresholds, which would make it hard for potential holdouts to get blocking positions. Second, the presence of the second vote (really a second way of counting the same vote) provided a simple check against a discriminatory offer. As a result, there was no need to restrict the terms of the offer itself. Safeguards against discrimination were embedded in the voting procedure. By definition, any restructuring that got a supermajority of the all-series vote and simultaneously cleared a slightly lower threshold in the single-series vote would be deemed fair.

However, there were limits on what could be achieved through a two-limb structure, both from an issuer and a bondholder perspective. Existing two-limb structures did not foreclose the "blocking stake” strategy. This mattered less in the euro area, where all but Greece continued to issue under local law and arguably retained the tacit option of using retro-CACs if all else failed. In foreign law bonds, raising the threshold for a blocking position in a series to $331 / 3$ or even $50 \%$ was not decisive. On the other hand, bondholders and lawyers voiced concerns - notably in London - about dropping the threshold on bond-by-bond voting below 50\%, for fear of 
discrimination. For bondholders, virtually all plausible series-by-series voting scenarios led to game-theoretic options that could be exploited by an aggressive issuer or a determined holdout.

Allowing a single vote across series using an aggregation clause functionally similar to Greek retro-CACs offers an obvious alternative to two-limb aggregation. It eliminates the series-byseries tally, and creates a choice between a restructuring binding on all polled creditors, or a restructuring that fails for all. The result is a clean decision for all involved. This has advantages for the issuer, but also for many creditors.

The decision facing creditors in a bond by bond vote is more complex than is sometimes realized. In a market that trades, there is an advantage to holding the same instrument as the others. The prospect of being left with an old, illiquid bond after the rest of the debt stock is restructured is unwelcome to a typical, non-activist bondholder, who is not willing to invest time and resources in litigation. Such a bond holder even may be willing to accept less favorable restructuring terms so as not to be left behind. However, it is virtually impossible for her to convey this preference hierarchy in the series by series restructuring framework. A bond holder who does not like the terms offered by the debtor only can reject them by voting no. But by voting no, she may cause only her series to drop out of the restructuring, and be left as an "unwilling holdout." Put differently, a creditor may prefer to remain in the old bond if enough other creditors reject the debtor's offer of new bonds-but also may prefer to participate in a restructuring if it achieves the critical mass to go forward. In series by series restructuring, there is no way for a bondholder to vote against the debtor's proposal, and, at the same time, agree to be bound by it if there are sufficient votes across the debt stock for the deal to go forward. ${ }^{12}$

The argument for a single aggregated vote across all series is especially compelling if the issuer is seeking a comprehensive restructuring to restore its solvency after a payment default. Bond holders typically have the right to accelerate, which means that the maturity structure collapses after a default, as the full principal on all bonds is due. Each holder's stake is then represented by the par value of its bond. In such circumstances, a vote of all bonds based on the par value of their bonds is easy to justify and execute. The main risk of aggregation in a case like this is that a super majority of creditors could join the issuer and gang up on a minority of their fellow creditors, forcing them to bear discriminatory losses. We return to this problem later in this section.

Aggregated voting is not needed for all cases. If the issuer's problem is caused by a single bond maturing in the near future, amending that bond's payment terms should be sufficient to address

\footnotetext{
12 The non-activist bondholder faces two questions in a complex series-by-series restructuring, but has only one vote with which to respond: first, is the overall restructuring acceptable; second, is the restructuring unfair to a particular series. A single aggregated vote with constraints on the offer to assure fairness reduces the question posed to the bond holder to "is the overall restructuring acceptable."
} 
it. The single-bond scenario thus poses another design question: whether aggregation procedures should replace existing series-by-series voting, or serve as one of several restructuring options option.

Limiting the number of voting procedures gives investors more certainty ex ante about the range of possible outcomes in distress. Such certainty comes at the cost of foreclosing flexibility to tailor restructurings to the issuer's circumstances. There are clearly cases when an individual bond might need to be restructured without a comprehensive restructuring, and there are also clearly cases where a comprehensive restructuring is needed. Informal consultations with investors revealed no interest on their part in foreclosing the targeted amendment option for one or several series. As a result, single-limb aggregation became an option, not a requirement.

The ICMA model ultimately included three voting procedures: series-by-series amendment, twolimb aggregation, and single-limb aggregation. The last option, which offers the strongest shield against opportunistic free-riders, is only available under a set of restrictive conditions that serve as safeguards for investors. We discuss the safeguards later in this Part.

Finally, investors should know ahead of time how their votes would be counted. When the sovereign borrower has a menu of options for restructuring, it commits to disclose its choice before taking the poll. Any votes cast are only valid for that procedure. If, for example, an aggregated vote fails to obtain the needed super-majority of all bond holders but there are enough votes to amend the terms of several individual bond issues, the issuer cannot simply recount the votes to restructure the few issues. In theory, the issuer could conduct a second vote but those voting to restructure their bonds individually would know that the aggregated vote had failed, and thus not all bond holders would be joining in the restructuring.

Offer Terms. As we noted earlier, there is no need to restrict the terms of the offer ahead of time in series-by-series or two-limb aggregated vote. The series-by-series voting threshold substitutes process fairness for substantive oversight. An offer than is unfair to the holders of a one series would be rejected by the holders of that series. Single-limb aggregation removes this protection along with the risk that it could be used strategically by investors looking to secure a better payoff than other creditors.

Single-limb aggregation thus poses an additional challenge for designing substantive safeguards. The notion of voting by class of creditors comes from corporate bankruptcy. Bankruptcy classification and voting are supervised by the judge, who has the authority to protect minority creditors from an unfair or abusive offer. Relying entirely on contract though means that the court's role is more limited, and is focused on assuring that the terms of the contract are followed. Only in extreme cases, where minorities are effectively expropriated, have courts intervened to invalidate the vote. ${ }^{13}$

\footnotetext{
${ }^{13}$ Assenagon Asset Management SA v Irish Bank Resolution Corporation Ltd
} 
The ICMA model resolves this problem by limiting single-limb aggregation to cases where the sovereign makes a "uniformly applicable” offer to all its creditors. The meaning of was actively debated in working groups and informal consultations. ICMA chose to define a uniformly applicable offer quite narrowly, as an identical offer made to the different bond holders per unit of par claim.

Identical offer can be an offer of identical terms (a prix fixe menu), or an offer to choose from the same a la carte menu. In either case, the same offer must be available to all creditors. There is no prix fixe menu for one set of bonds and an a la carte menu for another. Menu terms can differ (for example, options of “par” and “discount” bonds, common in restructurings), so long as everyone gets to choose from the same menu. If one of the restructuring options on the menu is obviously better than the others, all the bondholders will choose that option. To avoid arguments over equivalence among menu items, the issuer was required to offer identical exit instruments to all.

The "same offer/ same instruments" condition is more restrictive than other possible alternatives. For example, "same” is more limiting than "equal” or "equivalent.” Conflicting arguments over equal treatment in the pari passu litigation involving Argentina demonstrate that equality can be in the eye of the beholder. Binding creditors who vote no into the instrument received by creditors who vote yes limits controversy over the equivalence of terms. ${ }^{14}$

In restructuring negotiations, the equivalence of different instruments with different cash flows depends on the interest rate used to discount the cash flows. Defining the requirement tightly limits the issuer's flexibility, but it also reduces the scope for disagreement over discount rates used to calculate the net present value (NPV) of cash flows to determine whether they are "equal.” It is harder to claim discrimination if every investor is bound to receive an identical instrument.

The option to use single-limb aggregation to achieve identical NPV reduction (equivalent losses) across different instruments was ruled out in working group and market negotiations precisely to avoid endless arguments over appropriate discount rates. Foreclosing NPV-neutral exchanges using single-limb aggregation was a difficult choice. Some stakeholders, including issuers, sought to include NPV-neutral exchanges in single-limb aggregation to encourage participation among holders of near-dated bonds. However, putting NPV-neutral exchanges up to a single vote also raises hard issues. The simplicity of "same offer/same instruments" would be gone, replaced with arguments over what constituted equal NPV. What curve would be used? Who would

[2012] EWHC 2090 (Ch); see also http://www.ft.com/cms/s/0/a0866b3e-ae74-11e2-831600144feabdc0.html\#axzz3izZIxTv3

${ }^{14}$ Mexico's first New York law bond included that the offer needed to be the same to all bonds, but did not further clarify that the offer needed to be "on the same terms", though the context supported the same terms interpretation. Mexico has since clarified the clause to conform to ICMA's New York law template. A few outstanding bond issues that copied Mexico still miss the four words, though subsequent issues are following ICMA template. From Working Group, IMF Board, and ICMA discussions it is clear that this was not supposed to be a departure. 
decide the right discount rate for comparing future cash flows, especially in a world where the "exit" yield that equalizes different cash flows has to be decided ex ante but is only knowable ex post? Would different curves would be used for bonds denominated in different currencies? Using a dollar curve for euro-denominated bonds seems unfair, but using different curves would imply that bonds with equal par values and similar maturities denominated in different currencies would get different offers. Ultimately, the benefits of clarity, and the desire to follow the prevailing sovereign restructuring and corporate bankruptcy practice where voting is based on par value, won out. ${ }^{15}$

This outcome does not rule out NPV-neutral exchanges, which protect the maturity structure and generally favor investors at the front end of the curve. Such exchanges remain appropriate under some circumstances; they are typically used to avoid a payment default. However, because they would not meet the "same terms/ same instrument" test, they would have to proceed using seriesby-series or two-limb aggregated votes. Investors would know that if the NPV-neutral exchange failed, it could be followed by default and a comprehensive restructuring using single-limb aggregation. The single-limb backstop could help encourage participation in the exchange from holders of near-dated bonds. However, the restructuring could not bind near-dated series unless they voted for it.

Working group discussions also revealed that creditors needed assurance that they would not be penalized for voting no. The same offer means that investors who voted against the restructuring proposal/ exchange would receive the same instruments, on the same terms, as investors who voted for the deal. Rewards for voting, and for voting early, need not be prohibited so long as they were available to all bondholders pooled in a single-limb aggregated vote. ${ }^{16}$

Lesser complexities arise within the "same terms/same instrument” parameters, for example, with respect to interest. In sovereign restructuring practice, interest that has been accrued but not paid before the default is often paid out in the exchange, providing a bit of cash to some investors and equalizing the treatment of different bonds (otherwise, a bond that received a coupon payment just prior to default is better positioned than bonds were about to receive a coupon payment). The treatment of past due interest - interest that accrues after a default - is more contentious. Creditors, especially creditors with high coupon bonds, always want some recognition for past due interest; however, restructuring practice varies in this area, while the amounts at stake can be substantial. ICMA clauses define "same offer" as the same offer on par values, the same offer on all interest that had been accrued prior to the default and the same offer on all past-due interest. Thus the offer to individual bonds could differ a bit, so long as the offer made on all par, all accrued by unpaid interest and all past due interest was the same. For example, offering no payment of past-due interest would meet the criteria of providing the same

\footnotetext{
15 IMF, 2014a.

${ }^{16}$ Azevedo v Imcopa, see also http://ftalphaville.ft.com/2013/04/22/1469152/the-consent-of-the-bondholdergoverned/
} 
offer to all similarly situated creditors. The exact treatment of past-due interest would thus be a subject of negotiation, or, in the absence of formal negotiations, a critical decision that the issuer and its advisors would need to make before approaching their creditors with a comprehensive restructuring offer.

One interesting question is how to value zero coupon bonds for the purposes of a restructuring. Zero coupon bonds are one example of a broader category of bonds issued at discount to par. The answer is relatively simple: calculating the accrued principal value of the zero coupon bond, and using the adjusted par value as the basis for voting (Box 1).

Other more complex features of a bond - embedded options - could be addressed in a similar way, when relevant. The logic of a uniformly applicable offer is that it makes "same offer for the same features" so a bond with an embedded warrant might receive a different offer than a plain vanilla bond. But all warrants would need to get the same offer per equal warrant, and the

\section{Box 1: Voting with Zero-Coupon Bonds}

ICMA model clauses indicate that a uniform offer must provide the same consideration or menu of consideration to each series of bonds, and that the quantity of consideration is based on the par amount of the bondholder's claim. For most bonds, determining par claim is straightforward: the face principal amount of the bond. However, there are some bond structures where the face principal amount is not the same as a par claim. The most common is a zero-coupon bond. A zero-coupon bond is issued for a price below par, and the bondholder earns the difference between this issue price and par over the life of the bond. A zero-coupon bond is a special case of the more general class of bonds with an "original issue discount." To recognize the full at-maturity principal claim of these bonds in a restructuring would be dilutive to other bond series, since it is equivalent to recognizing the future coupons of a par-issue coupon bond. Bankruptcy law makes special provision for bonds with original issue discount, generally disallowing any claim for “unamortized discount.” Likewise, the Euro Area Model CACs include a method for calculating, for vote-counting purposes, an adjusted principal amount for zero-coupon bonds. This method consists of discounting the face amount of the bond from its scheduled maturity date to the record date of the restructuring, using as a discount rate the yield-to-maturity of the instrument at its issuance date ${ }^{1}$. The ICMA clauses did not specify how the par claim for zeros should be calculated, but it is clear that there are good models for any emerging market that wants to issue a zero and include it in the aggregation pool.

par value of all plain vanilla bonds would need to receive the same offer. The flexibility in the pooling procedures in the ICMA model clauses also would help to manage a complex debt stock.

Yet the need for these features should not be overstated. Most emerging market bonds governed by foreign law are fairly straight forward instruments - bullet maturity, coupon, and fairly standard rather than bespoke legal provisions.

Voting Thresholds. Choosing a voting threshold sufficient to assure fair treatment for all creditors is a distinct design challenge with single-limb aggregated CACs. 
Market practice for series-by-series voting is not uniform. New York law bonds typically allow holders of $75 \%$ of outstanding principal to bind all holders in a series. However, variation in effective thresholds within and across New York and London markets is enormous (Bradley and Gulati 2012). Quorum requirements and alternative thresholds for postponed meetings make it hard to discern the effective threshold in any given case. English law bonds typically allow amendment by a super-majority of two-thirds or three-quarters at a quorate meeting. If the quorum is $50 \%$ of the bond's par value, a supermajority of that quorum could amend the bonds. Postponed meetings may result in a quorum as low as 25\%; however, in practice, low participation has not been a problem in sovereign restructurings.

There is a case that the voting threshold in single-limb aggregated voting should be high. The vote is binding on all and thus should have broad support from investors. For this reason, the ICMA clauses adopt the highest threshold consistent with existing market practice, a minimum requirement of $75 \%$ percent of the eligible stock.

Only affirmative votes in favor of the restructuring count toward the total, abstention is an effective "no" vote. This approach to tallying the votes rests on the assumption that there is little risk of passive creditors inadvertently blocking a restructuring they would want to support. The alternative to a comprehensive restructuring of all bonds is usually a comprehensive default, and a prolonged period of non-payment. Under the circumstances, creditors should be motivated to participate.

Disenfranchisement. Institutions controlled by the issuer often can hold bonds that are a part of the restructuring. State-owned banks and state-owned pension funds, for example, may own their own countries international law bonds. A country may also buy back its bonds at a discount, and retain their votes. Emerging market series-by-series and two-limb aggregated CACs, as well as the G-10 model clauses issued in 2002, all included provisions disenfranchising bonds held by institutions controlled by the sovereign. Control was normally defined as majority ownership or control of the board of directors. Bonds held by a privately owned bank regulated by the issuer would not lose their vote, but bonds owned by a state owned bank would. These provisions were carried over into the 2014 ICMA model clauses.

As we noted earlier, euro area aggregated CACs contain disenfranchisement provisions that are more permissive for the issuer. They allow voting by entities that might be owned or controlled by the sovereign, but have “autonomy of decision.” National central banks, state-owned banks, and public pension funds are the most likely bondholders in this category. This formulation of disenfranchisement is unique to the euro area. Working group members considered it inappropriate to extend this treatment to foreign-law debt of all mature and emerging market issuers

Pooling or sub-aggregation. Two-limb aggregation CACs allow the debtor to pool series for purposes of taking an aggregated vote. This feature gives issuers the capacity to classify bond 
holders for voting purposes. Aggregation procedures then apply within a pool, rather than across the entire debt stock.

The sub-aggregation option can be important in a complex debt restructuring involving a variety of bond issues with different features and economic interests. Similar bonds - for example, all bonds denominated in the same currency, or all zero coupon bonds - could be placed in the same voting pool. Particularly complex bonds could also be placed in their own pool, and restructured through a bond by bond vote.

With two-limb aggregation, pooling presents little risk of abuse. For example, in the euro CACs, each sub-aggregated series still gets to vote its own interests, and must muster at least $50 \%$ of the outstanding debt to approve a proposal. On the other hand, single-limb aggregation does not have the safeguard of the series vote. The remaining safeguards are in the $75 \%$ approval threshold, and "same offer/same instrument" criterion. In theory, it is plausible for the debtor and its advisers to gerrymander a complex series of pools to discriminate among them. The "same offer/same instrument” constraint would apply within each pool, but not across pools.

One safeguard considered but rejected was a requirement that all bonds in the same pool must have contiguous maturities. This would limit obvious attempts to gerrymander the voting pool. But it also generates additional complexity - notably when it comes to determining the maturity of instruments with embedded put and call options. There are also concerns about requiring the pooling of radically dissimilar bonds purely on contiguity grounds.

The ICMA model clauses did not in the end include any limitations on sub aggregation and pooling. In part this is because the issuer normally would not want to splinter the voting pools too much, as a large number of pools reduces the basic benefit of aggregation. An issuer's interest in a successful restructuring also creates incentives to use pooling and sub-aggregation in a way that its investors recognized made sense, so as to maximize the odds of a successful vote.

The most potent protection against gerrymandering lies in the sovereign's need to get all bond holders to accept the deal. If a series is placed in a pool that is perceived by other bond holders as getting preferential treatment, others who consider themselves similarly situated would vote against the deal. Large discrepancies in treatment across different pools would only be accepted if the holders of the bonds in each pool believed their individual offer was fair, and all similarly situated creditors would receive similar treatment.

Information disclosure. Disclosure of restructuring procedures and terms offered to all creditors (not just bondholders) is essential to protect the legitimacy of a vote of all creditors. This is especially important when multiple voting procedures could be used across diverse instruments. In addition, a fair vote requires equal access to information relevant to the restructuring decision. Investors should know not only the offer than they are receiving, but also how the restructuring of their claims fits into the issuers' broader financial reorganization. ICMA's model 
consequently provides a covenant to assure full disclosure of the issuer's restructuring plans and financial condition.

The model information covenant requires the following:

1. Full disclosure of any offers being made to other bonds and tradable securities. Not all bonds have aggregation clauses, and not all bonds with aggregation clauses vote as part of the same pool. Those participating in the aggregated vote should know the terms being offered to similar instruments that are not voting alongside them. If the sovereign makes use of the pooling option, the bond holders should know which bond series is in which pool, and what package of new instruments and other consideration is being offered to holders of the instruments in each pool.

2. Disclosure of the issuer's intentions vis a vis creditors other than bond holders. This is a lower standard than the standard for bond holders, as it stops short of requiring detailed disclosure of offer terms. More broadly, the standard for disclosure should be higher for similarly situated creditors, and should be adapted to the instrument and restructuring process involved. Local law instruments differ from foreign law instruments. Official (Paris Club) credits historically have differed from commercial bank loans and marketable debt securities. Such claims have been restructured through different processes; in particular, there may be no offering terms to disclose. Instead, the issuer may be able to disclose its domestic debt restructuring plans and its goals for the negotiations with bilateral creditors (the latter would require Paris Club consensus to take effect). Bond holders who need more certainty on the treatment of other creditors may have to defer the restructuring of their own claims until that treatment is known.

3. Disclosure of the government's IMF program documentation and any new financing that it is receiving, including any new official financing.

Taken together, this information falls short of what might be found in a plan of adjustment in a bankruptcy proceeding, which makes clear the treatment of all relevant stakeholders and creditors. But the price of completeness is often delay. Building on existing practice, it seemed reasonable to require the issuer to disclose its full plan of adjustment for all bonded debt, and to allow a vote on the bonded restructuring to proceed even in the absence of full clarity on the treatment of all other groups of creditors

The required disclosure builds on, but goes beyond, prior models including Uruguay's 2003 clause and the G-10/ ICMA documentation standards (G10 2002, ICMA 2004). The net effect is a substantial increase in the disclosure required from an issuer at the time of its restructuring.

Calculation agent. Without a bankruptcy court to certify claims, a contractual mechanism is necessary to compute the par value of complex instruments, and to fix the exchange rate used for 
calculating the value of bonds denominated in different currencies. If a country issues zero coupon bonds -- or other bonds sold at a significant discount (original issue discount), the par value of the bond for purposes of the vote may be defined to be something other than its face value. For example, as discussed in Box 1, the euro CACs had an elegant definition of the current par value of a zero coupon bond - its accreted value, based on the interest rate on issuance.

Scope of aggregation across jurisdictions. ICMA aggregation clauses are limited to bonds governed by foreign law. Bonds governed by English law, New York law, Swiss law and Japanese law could be combined in a single vote, provided all the instruments had the needed contractual provisions. Bonds governed by the sovereign issuer's own law would not be included in the aggregation pool.

This differs from the euro-CACs, which were included in domestic and foreign-law instruments. Both domestic and foreign-law bonds can be part of the same aggregation pool under the euro area model.

There are several reasons for this difference.

Documentation used in domestic-law bonds is highly idiosyncratic, reflecting each country's own history, legal and institutional traditions. Harmonizing the language used in local law debt around the world would be a much deeper change than either harmonizing euro area debt documentation, or the documentation used in New York and English law bond issues. Institutional integration and an existing treaty framework make the task easier in the euro area, while New York and English law debt documentation is already standardized in many respects.

In addition, investors in foreign law bonds have voiced substantive objections to being aggregated in a single pool with the holders of local law debt. While foreign participation in local markets has grown, in most countries, domestic investors - including banks, insurance companies and pension funds regulated by the borrowing sovereign - hold the bulk of local law debt. The incentives facing domestic and foreign investors typically differ; the sovereign also has more tools to influence the behavior of its own residents. From the foreign investors' perspective, putting domestic and foreign law bonds in a single pool under one-limb aggregation risks having their votes overwhelmed by those of local residents, while making it difficult to assess whether domestic and foreign investors were offered "uniformly applicable” terms. On the other hand, it would be difficult to verify whether local residents were offered the same terms as their foreign counterparts, since the sovereign could use side payments, regulatory carrots and sticks unseen from the outside to encourage participation. Finally, and most importantly, countries already have scope for addressing collective action problems in their local law bonds. For example, Greece illustrated that voting mechanisms can be introduced by statute as necessary. Limiting the voting pool to bonds governed by foreign law provided a simple and pragmatic solution that reflected all these concerns. 


\section{Engagement}

ICMA's 2004 model CACs included recommended provisions for engagement with creditor committees in the event of a restructuring (ICMA 2004). ICMA kept the recommendations in 2014, although they were not discussed in the working group and underwent minimal revision. This did not reflect hostility to creditor committees among any of the participants, but rather two other factors. First, unlike aggregated CACs and pari passu terms, creditor committees and engagement are already permitted in all existing sovereign bond contracts. Bondholders are free to call meetings and deputize representatives, typically by a vote of $25 \%$ of outstanding principal. Pre-committing to particular engagement procedures did not appear to have the urgency of other reforms. Second, engagement terms recommended in 2004 failed to catch on in New York, and were far from universal in London. This observation suggests that more research and design work was in order before extending official endorsement to any particular form of engagement.

Widespread introduction of robust aggregation clauses should lead to more engagement with creditors during the restructuring process. An issuer has a stronger incentive to negotiate with a committee of creditors under aggregated voting, since the committee is more likely to deliver a successful restructuring. Without aggregation, bondholder committees do not guarantee participation by creditors who are not committee members. Under an expansive aggregated voting regime, a sovereign debt restructuring can secure $100 \%$ participation and virtually eliminate holdouts with the support of $75 \%$ of their creditors, making agreement with $75 \%$ more valuable. In a complex restructuring with multiple pools of creditors and different offers to different pools, one way of avoiding disagreement on the composition of creditor pools is through close engagement with relevant creditor groups.

\section{Conclusions}

The issuance and adoption of ICMA model aggregated CACs since 2014 testifies to the importance of design and process in reforming sovereign debt restructuring. In a stark contrast with the contract reforms of the late 1990s and early 2000s, this generation of reforms won support from issuers, civil society groups, the sovereign debt bar, market participants, and international organizations. Agreement among diverse stakeholders on the design of a new model for the documentation for sovereign bonds issued by emerging markets and governed by foreign law paved the way for a relatively rapid and uncontroversial - though still incomplete shift in documentation standards in both New York and England.

This reflects process learning, and the buy-in achieved through the Treasury-initiated consultation process. It also reflects the maturity of the market. The debate wasn't driven by symbolism, or fear that preparing for default and restructuring would encourage default and restructuring. Rather, making inevitable restructurings less chaotic and more predictable is now 
recognized to be a part of a healthy market. Advance preparation allows a faster path out of default, and makes it easier for investors to price the likely outcome of the restructuring

A low-key debate shouldn't mask the scale of the change. Events since 2012 have demonstrated the value of well-designed contract provisions to guide restructuring. The new provisions went significantly beyond any existing contractual model, and represent a far bigger substantive change in sovereign bond documentation than what had emerged from the public battles of the 1990s and early 2000s. While it will take some time for the existing stock of bonds with old CACs - or in some cases, no CACs - to turn over, the new aggregation provisions provide the contractual basis for replicating one key feature of bankruptcy - aggregated voting creditor classes.

At the same time, contract reform cannot fully replicate a full-blown bankruptcy regime based in statute or treaty. Clauses allowing for aggregated voting will help solve problems of coordination among different bond series, but do not attempt to provide a framework for coordination across the full set of claims - local law bonds, traditional Paris Club creditors, short-term bank lenders backed by a sovereign guarantee - on a distressed sovereign borrower.

More ambitious reform will take more substance and process learning, and in all likelihood, more trauma.

\section{Bibliography}

Ahmed, Faisal Z., Laura Alfaro, and Noel Maurer. 2010. "Lawsuits and Empire: On the Enforcement of Sovereign Debt in Latin America." Law and Contemporary Problems 73 (no. 4): 39-46.

Ash, Tim. 2014. Standard Bank. Weekly market commentary.

Becker, Torbjorn, Yunyong Thaicharoen, and Anthony Richards. 2003. "Bond Restructuring and Moral Hazard: Are Collective Action Clauses Costly?” Journal of International Economics 61 (no. 1): 127-161.

Bi, Ran, Marcos Chamon, and Jeromin Zettelmeyer. 2011. “The Problem That Wasn't: Coordination Failures in Sovereign Debt Restructurings.” IMF Working Paper 11/265, Washington, D.C.

Bradley, Michael, Gulati, Mitu. 2012. “Collective Action Clauses for the Eurozone: An Empirical Analysis.” Working Paper. http://papers.ssrn.com/sol3/papers.cfm?abstract_id=1948534 (accessed January 13, 2013).

Brooks, Skylar, and Domenico Lombardi. 2015. “Sovereign Debt Restructuring: Issues Paper.” CIGI Papers No. 64, Waterloo, Ont.

Brooks, Skylar, Martin Guzman, Domenico Lombardi, and Joseph E. Stiglitz. January 2015. "Identifying and Resolving InterCreditor and Debtor-Creditor Equity Issues in Sovereign Debt Restructuring.” CIGI Policy Brief No. 53, Waterloo, Ont. www.cigionline.org/publications/identifying-andresolving-inter-creditor-and-debtorcreditor-equityissues-sovereign-de.

Buchheit, Lee C. 1995. "How to Negotiate Eurocurrency Loan Agreements.” Euromoney, 
London.

— . 1998. "Majority Action Clauses May Help Resolve Debt Crises.” International Financial Law Review 17.

Buchheit, Lee C., and Mitu Gulati. 2002. “Sovereign Bonds and the Collective Will.” Emory Law Journal 51 (no. 4): 1317-1363.

Buchheit, Lee C and Jeremiah S. Pam. 2004. “The Pari Passu clause in Soveriegn Debt Instruments.” Emory Law Journal. Volume 53, special edition. 870-922.

Buchheit, Lee C., Mitu Gulati, and Ignacio Tirado. 2013. “The Problem of Holdout Creditors in Eurozone Sovereign Debt Restructuring.” Duke Law Working Paper.

IMF Staff Papers 35: 644.

Chamon, Marcus, Julian Schumacher, and Christoph Trebesch. 2015. "Foreign Law Bonds: Can They Reduce Sovereign Borrowing Costs?” University of Munich (Economics) Working Paper.

Claessens, Stijn, Daniella Klingbiel, and Sergio L. Schmuckler. 2007. “Government Bonds in Domestic and Foreign Currency.” Review of International Economics 15 (no. 2): 370403.

Clare, Andrew, and Nicolas Schmidlin. 2014. "The Impact of Foreign Governing Law on European Government Bond Yields.” City University London (Cass) Working Paper.

Clifford Chance. 2014. "New ICMA Collective Action and Pari Passu Clauses." www.cliffordchance.com/briefings/2014/10/new_icma_sovereigncollectiveactionandpar.h tml.

Choi, Stephen, and Mitu Gulati. 2006. “Contract as Statute.” Michigan Law Review 104: 1129_ 1173.

Choi, Stephen, Mitu Gulati, and Eric A. Posner. 2011. "Pricing Terms in Sovereign Debt Contracts.” Capital Markets Law Journal 6 (no. 2): 163-187.

Cline, William. 1995. International Debt Reexamined. Peterson Institute: Washington DC

Das, Udaibir S., Michael G. Papaioannou, and Christopher Trebesch. August 2012. "Sovereign Debt Restructurings 1950-2010: Literature Survey, Data, and Stylized Facts.” IMF Working Paper/12/203, Washington, D.C.

Diaz de Leon Carrillo, Alejandro. 2016 “Mexico's Adoption of New Standards in International Sovereign Debt Contracts - CACs, pari passu and a trust indenture.” Capital Markets Law Journal (forthcoming 2016)

Du, Wenxin, and Jesse Schreger. 2015. “Local Currency Sovereign Risk.” Harvard University (Economics) Working Paper.

Duffie, Darrell, Lasse Hejje Pedersen, and Kenneth J. Singleton. "Modelling Sovereign Yield Spreads: The Case of Russia.” 58 (no. 1): 119-159.

Duggar, Elana. 2013. “Argentina Is Unique-Implications for Sovereign Debt Restructurings.” A Cato Institute Forum, held December11.

Economic and Financial Committee of the European Union. 2013. "Common Understanding on Implementing the EU Commitment Regarding the Use of Collective Action Clauses (CACs).” http://europa.eu/efc/sub_committee/pdf/common_understanding_cacs_en.pdf (accessed January 15, 2013).

Economic and Financial Committee of the European Union, Sub-committee on Sovereign Debt Markets. 2014. "Implementation of the EU Commitment on Collective Action Clauses in Documentation of International Debt Issuance, Brussels, November 12” (ECFIN/CEFCPE(2004)REP/50483 final). 
http://europa.eu/efc/sub_committee/pdf/cacs_en.pdf.

—. 2012. "Euro Area Model CAC 2012."

http://europa.eu/efc/sub_committee/cac/cac_2012/index_en.htm (accessed April 23, 2013).

The Economist. 2013, April 20. “An Illusory Haven: What Lessons Should Investors Learn from the Argentine and Greek Restructurings?”

Eichengreen, Barry. 2003. "Restructuring Sovereign Debt.” Journal of Economic Perspectives 17 (no. 4): 75-98.

Eichengreen, Barry, and Ricardo Hausmann.1999. "Exchange Rates and Financial Fragility.” Proceedings-Economic Policy Symposium-Jackson Hole, Federal Reserve Bank of Kansas City, 329-368.

Eichengreen, Barry, and Ashoka Mody. 2004. "Do Collective Action Clauses Raise Borrowing Costs?” Economic Journal 114 (no. 495): 247-264.

Eichengreen, Barry, and Richard Portes. 1995. "Crisis? What Crisis? Orderly Workouts for Sovereign Debtors.”

Fisch, Jill E. and Gentile, Caroline M. 2004. "Vultures or Vanguards?: The Role of Litigation in Sovereign Debt Restructuring" 53 Emory L.J. 1047 .

Franco-German Declaration. 2010. http://ebookbrowse.com/franco-german-declarationdeauville-18-10-2010-pdf-d221247911 (accessed January 15, 2013).

Gadanecz, Blaise, Ken Miyajima, and Chang Shu. 2014. "Exchange Rate Risk and Local Currency Sovereign Bond Yields in Emerging Markets.” BIS Working Paper 474.

Gelpern, Anna. 2014. “A Sensible Step to Mitigate Sovereign Bond Dysfunction.” http://blogs.piie.com/realtime/?p=4485\#.VBlnUiofqW8.email.

—. 2016. "Domestic Debt and Alien Comforts.” Capital Markets Law Journal (forthcoming). Gelpern, Anna, and Mitu Gulati. 2006. "Public Symbol in Private Contract: A Case Study.” Washington University Law Quarterly 84: 1627-1715.

—. 2009. "Innovation After the Revolution: Foreign Sovereign Bond Contracts Since 2003." Capital Markets Law Journal 4 (no. 1): 85-103.

—. 2013. “The Wonder-Clause.” 2013. Journal of Comparative Law 41: 367-385. Also Georgetown Law Faculty Publications and Other Works. Paper 1281. http://scholarship.law.georgetown.edu/facpub/1281.

—. 2015. "Contract Terms and Sovereign Debt Pricing: The View from a Government Debt Manager's Perspective.” Duke Law School Working Paper.

Gros, Daniel, and Thomas Mayer. 2010. "How to Deal with Sovereign Default in Europe: Create the European Monetary Fund Now!” Center for European Policy Studies 202. www.ceps.eu/ceps/download/2912 (accessed January 13, 2013).

G10. 1997. The Resolution of Sovereign Liquidity Crises. Bank of International Settlements. August

- 2002. Report of the G-10 Working Group on Contractual Clauses. September. www.bis.org/publ/gten08.pdf (accessed January 13, 2013).

G22. 1998. Report of the Working Group on International Financial Crises. October. http://www.imf.org/external/np/g22/ifcrep.pdf

Gugiatti, Mark, and Anthony Richards. 2003. "The Use of Collective Action Clauses in New York Law Bonds of Sovereign Borrowers.” Working Paper Series. http://papers.ssrn.com/sol3/papers.cfm?abstract_id=443840 (accessed January 15, 2013). Gulati, Mitu, and Frank Smets. 2013. “The Evolution of Eurozone Sovereign Debt Contracts.” 
Unpublished Manuscript.

Häseler, Sönke. 2009. “Collective Action Clauses in International Sovereign Bond Contracts— Whence the Opposition?” Journal of Economic Surveys 23 (no. 5): 882-923.

Inter-American Development Bank. 2006. Living with Debt: How to Limit the Risks of Sovereign Finance, 2007 Report. Washington, D.C.

International Capital Market Association. 2004. "Standard Collective Action Clauses (CACs) for the Terms and Conditions of Sovereign Notes. October 28.

International Capital Market Association. 2011. Response to Consultation Dated 23 July 2011 on Collective Action Clauses to be Included in Euro Area Sovereign Securities. www.icmagroup.org/assets/documents/Maket-Practice/Regulatory-Policy/SovereignDebt-Information/ICMA\%20CAC\%20response\%202\%20September\%202011.pdf (accessed January 10, 2013).

— - June 2014a. ICMA Sovereign Bond Consultation Paper Supplement.

— - August 2014b. Standard Aggregated Collective Action Clauses (“CACS") for the Terms and Conditions of Sovereign Notes.

International Monetary Fund. 2003a. "Proposed Features of a Sovereign Debt Restructuring Mechanism.” Washington, D.C. www.imf.org/external/np/pdr/sdrm/2003/021203.pdf (accessed January 13, 2013).

—. 2003b. "The Restructuring of Sovereign Debt—Assessing the Benefits, Risks, and Feasibility of Aggregating Claims.” Washington, D.C. www.imf.org/external/np/pdr/sdrm/2003/090303.pdf.

—. April 2013. "Sovereign Debt Restructuring—Recent Developments and Implications for the Fund's Legal and Policy Framework.” Washington, D.C. www.imf.org/external/ np/pp/eng/2013/042613.pdf.

— - September 2014a. Strengthening the Contractual Framework to Address Collective Action Problems in Sovereign Debt Restructuring. Staff Report. Washington, D.C.

— - June 2014b. The Fund's Lending Framework and Sovereign Debt-Preliminary Considerations. IMF Staff Report. Washington, D.C.

JP Morgan. 2014. 6 November. Conference call. Transcript available on request.

Krueger, Anne. April 2002. “A New Approach to Sovereign Debt Restructuring.” International Monetary Fund, Washington, D.C.

Makoff, Gregory, and Robert Kahn. February 2015. "Sovereign Bond Contract Reform: Implementing the New ICMA Pari Passu and Collective Action Clauses." CIGI Papers No. 56, Waterloo, Ont. www.cigionline.org/publications/ sovereign-bond-contractreform-implementing-newicma-pari-passu-and-collective-action-c.

Miyajima, Ken, Madhusudan Mohanty, and Tracy Chan. 2012. "Emerging Market Local Currency Bonds.” BIS Working Paper 391.

Mody, Ashoka. 2004. “What Is an Emerging Market?” IMF Working Paper177, Washington, D.C.

Mauro, Paolo, Nathan Sussman, and Yishay Yafeh. 2006. "Bloodshed or Reforms? The Determinants of Sovereign Bond Spreads in 1870-1913 and Today.” CEPR Discussion Paper 5528.

Nordwig, Jens. 2015. "Legal Risk Premia During the Euro Crisis: The Role of Credit and Redenomination Risk.” University of Southern Denmark Working Paper.

Ocampo, José Antonio. 2014a. "Guest Post: Implications of the US Supreme Court Ruling on Argentina.” Beyond BRICS (blog), Financial Times, June 23. http://blogs.ft.com/beyond- 
brics/2014/06/23/guestpost-implications-of-the-us-supreme-court-ruling-onargentina.

Panizza, Ugo, et al. 2009. “The Economics and Law of Sovereign Debt and Default.” Journal of Economic Literature 47: 1.

Porzecanski, Arturo. 2006. "Dealing with Sovereign Debt: Trends and Implications," in Sovereign Debt at the Crossroads: Challenges and Proposals for Resolving the Third World Debt Crisis. Edited by Chris Jochnick and Fraser A. Preston. Oxford University Press: Oxford.

Porzecanski, Arturo. 2010. "When Bad Things Happen to Good Sovereign Debt Contracts: The Case of Ecuador," Law and Contemporary Problems, Fall.

Quarles, Randal. 2010. "Herding Cats: Collective-Action Clauses in Sovereign Debt-The Genesis of the Project to Change Market Practice in 2001 Through 2003.” Law and Contemporary Problems 73 (no. 4): 29-38.

Rosenberg, Christoph, Brad Setser, Ionnis Halikas, Brett House, Jens Nystedt, and Christian Keller. 2005. "Debt-Related Vulnerabilities and Financial Crises: An Application of the Balance Sheet Approach to Emerging Economies.” IMF Occasional Paper 240, Washington, D.C.

Roubini, Noriel, and Brad Setser. 2004. Bailouts or Bail-Ins? Responding to Financial Crises in Emerging Economies. Washington, D.C.: Institute for International Economics.

Schadler, Susan. August 2012. "Sovereign Debtors in Distress: Are Our Institutions Up to the Challenge?” CIGI Papers No. 6, Waterloo, Ont. www.cigionline.org/publications/sovereigndebtors-distress-are-our-institutions-upchallenge.

Schumacher, Julian, Christoph Trebesch, and Henrik Enderlein. 2012. Sovereign Defaults in Court: The Rise of Creditor Litigation 1976-2010 (December 16, 2012). http://papers.ssrn.com/ sol3/papers.cfm?abstract_id=2189997. Unpublished manuscript.

Setser, Brad. 2010. “The Political Economy of SDRM.” In: Barry Herman,Jose Antonio O’campo and Shari Spiegel et al. (eds.), Overcoming Developing Country Debt Crises. Herman, Barry,. Oxford University Press.

Setser, Brad, and Anna Gelpern. 2006. "Pathways Through Financial Crisis: Argentina.” Global Governance: A Review of Multilateralism and International Organizations 12, no. 4 (October): 465-487.

Stiglitz, Joseph, and Martin Guzman. 2014. “Argentina’s Griesafault.” Project Syndicate, August 7. www.projectsyndicate.org/commentary/joseph-e--stiglitz-andmartin-guzman-arguethat-the-country-s-default-willultimately-harm-america.

Sturzenegger, Federico, and Jeromin Zettelmeyer. 2007. Debt Defaults and Lessons from a Decade of Crises. Cambridge, Mass.: MIT Press.

Taylor, John B. 2002. "Sovereign Debt Restructuring: A U.S. Perspective.” In: Remarks at the Conference Sovereign Debt Workouts: Hopes and Hazards? Washington, D.C.: Institute for International Economics.

- 2007. Global Financial Warriors: The Untold Story of International Finance in the Post9/11 World. New York: Norton.

Tirado, Ignacio. 2012, December 8. “Sovereign Insolvency in the Euro Zone Public and Private Law Remedies.” http://ssrn.com/abstract=2186730.

Tovar, Camilo E. 2005. “International Government Debt Denominated in Local Currency: Recent Developments in Latin America.” BIS Quarterly Review (December). http://ssrn.com/abstract=1645868. 
United Nations. 2015. "Basic Principles on Sovereign Debt Restructuring Processes" (A/69/L.84). 11 September. At http://unctad.org/en/pages/newsdetails.aspx?OriginalVersionID=1074

Weidemaier, Mark C. and Anna Gelpern. 2013. ,"Injunctions in Sovereign Debt Litigation" Georgetown Law Faculty Publications and Other Works. Paper 1319. http://scholarship.law.georgetown.edu/facpub/1319

Weidemaier, Mark C. \& Mitu Gulati. 2014. “A People's History of Collective Action Clauses,” 54 Virginia Journal of International Law 1-95.

Weidemaier, Mark, Robert Scott, and Mitu Gulati. 2012. “Origin Myths, Contracts, and the Hunt for Pari Passu.” Law \& Society Inquiry 37. http://ssrn.com/abstract= 1633439 (accessed January 10, 2013).

Zettelmeyer, Jeromin, Christoph Trebesch, and Mitu Gulati. 2013. “The Greek Debt Restructuring: An Autopsy.” Economic Policy 28 (no. 75): 513-563. 